\title{
Evaluation of goodwill under Supply Side Reform
}

\author{
Rongjin $\mathrm{Li}^{1,}$, , Lin $\mathrm{Li}^{2, \mathrm{~b}}$ \\ ${ }^{1}$ School of Xi'an University of Architecture and Technology, Shaanxi, 710055, China; \\ ${ }^{2}$ School of Xi'an University of Architecture and Technology, Shaanxi, 710055, China. \\ a lirongjin12@126.com, b1344953475@qq.com.
}

Keywords: Supply Side, Evaluation of goodwill, Mergers and acquisitions

\begin{abstract}
In October 2015, General Secretary Jinping Xi proposed the term of "supply side reform" in his speech first. The most important thing of "supply side reform" is reforming the subject of supply ,so it need to reform enterprises. It aims at optimizing the allocation of resources, improving the efficiency of supply. Thus, promote the steady growth of the national economy. In this background, enterprise go to integrate resources gradually. One of the important ways is the mergers and acquisitions between enterprises, and the purpose is to achieve synergies, thus, improving the quality of supply. In the background of mergers and acquisitions, it is necessary for the enterprise to assess the value of goodwill. On the one hand, in order to determine the price of the transaction by confirming the assets. One the other hand, in order to manage goodwill effectively after the mergers and acquisitions, maximize excess returns, thus, increasing the business income.
\end{abstract}

\section{Introduction}

In October 2015, General Secretary Jinping Xi presided over the 11th meeting of the Central Leading Group, listened the report of economic structural reform issues from National Development and Reform Commission, Ministry of Finance and the People 's Bank of China, and have a discussion. General Secretary Jinping Xi proposed the term of "supply side reform" in his speech. And said that in the moderate expansion of aggregate demand, doing efforts to strengthen the supply side of the structural reform at the same time, doing efforts to improve the quality and efficiency of supply system , and enhance the sustained growth momentum of the economy ,thus promoting the level of China's social productivity to achieve overall leap. This is also the strict meaning of the first proposed "supply side reform" .So, what is "supply side reform"?

\section{Main Part}

\subsection{About Supply Side Reform}

To understand the supply side of reform, it is necessary to have some research on supply and demand. In the market economy, supply means that there must be a demand. It will drive the supply of production when there is a demand similarly. Supply and demand are interdependent, supply and demand together determining the market price at the same time. The current economic problems can be analyzed from the perspective of supply or demand. The so-called "supply side reform" is studying the economic development from the perspective of supply, analyzing the current economic problems from the supply side of the factors , solving the basic problems of China's economic development from the structural point and the factors of the supply side in fact. The basic principle of supply side reform is: $Y=A * k \beta * L(1-\beta)$.In this, $L$ represents the total labor force, $K$ representing the total capital, and A represents the efficiency level.

\subsection{Enterprise Reform under Supply Side Reform.}

In that way, how to carry out supply side reform? Or how to improve the efficiency level? How to measure the efficiency level? Or the A in total amount of economic activity in the analysis, or total factor productivity. Total factor productivity is a ratio of yield to factor input. Generally speaking, increasing total factor productivity is to make supply more efficient. Then it should start from the 
supply side , so the essential part is reforming the subject of supply. The subject of supply is enterprise generally. In our country enterprises can be divided according to the economic type, and it include: state - owned enterprises, collective enterprises, private enterprise, joint - stock enterprises, foreign companies and so on. As the supply side reform in China is a new concept ,it will be some difficult in advance, so we need some time to explore. The key to the reform of the supply side is the reform ,so the reform of enterprises is the first step in China's implementation of supply-side reform. There is two ways of enterprise reform, shareholding system reform of state - owned enterprises and Mergers and acquisitions of enterprises.

\subsection{Goodwill Assessment in Mergers and acquisitions}

Whether it is joint-stock reform or mergers and acquisitions, asset evaluation is required during the process. Asset evaluation must be based on the process of a clear assessment of basic matters, signing assessment agreement, preparation of evaluation plan, site investigation, gathering information, assessment of estimates, preparation of reports, report submission. The method of asset evaluation generally includes the method of income present value ,the method of reset costs, the method of current market price.

With the deepening of China's market economy, mergers and acquisitions has become an effective way for enterprises to grow and develop on the one hand, has become a way to enhance the effectiveness of the subject of the supply. According to incomplete statistics, a large number of companies in China have carried out a variety of mergers and acquisitions in different sizes, such as Lenovo's combining IBM's personal computer business, Geely acquiring Volvo and Didi Taxi announcing the acquisition of Uber China in this year early. It can be seen that $\mathrm{M}$ \& A of enterprise has been out of the country into the international, and this sign also shows that China's enterprises in the international market competitiveness continues to increase. More and more multinational business enterprises make the mergers and acquisitions increasingly complex. Mergers and acquisitions is conducive to the expansion and development of enterprises, enabling enterprises to get more new customers and greater market. From the perspective of supply side reform, mergers and acquisitions is an optimization of the subject of the supply. Mergers and acquisitions can be popularly understood as powerful combination or big fish eat small fish. Through effective and scientific mergers and acquisitions, you can get the effect of $1+1>2$. It can effectively integrate the resources within the enterprise and enhance the efficiency of enterprise operations, thereby improving the quality of supply through the mergers and acquisitions. Take mergers and acquisitions of upstream and downstream enterprises as an example ,it can accelerate the construction of the relevant industry chain and save the cost of business. For the production-oriented enterprises, it is able to provide customers with more inexpensive products.

In the enterprise asset evaluation, intangible assets are a very important part. From the traditional sense, intangible assets often refer to human resources, trademarks, patents, goodwill and so on. One of the most easily overlooked is goodwill. So what is goodwill? Goodwill is the profitability of the industry over the average earnings level, or the ability of obtain higher than normal return on investment. And this profitability may be due to the company has a superior geographical location, higher operating efficiency, good reputation, high-quality service, excellent human resources, advanced production techniques and so on.

Weidong Feng, Haiying Zheng(2013) pointed out that goodwill is different from intangible assets such as patents and trademarks, and it although exist in the enterprise, but both invisible and intangible, with non-identifiable and excess returns. And the enterprise goodwill comes from the enterprise core ability (different from the general ability) [1]. In the international arena, many CEOs agree that goodwill is the most important factor that makes a company unique in the market and is the most important asset. Therefore, we must have a good understanding of the assessment of goodwill. About the importance of goodwill, Frank Brown(2015)said that goodwill usually accounts for $60 \%$ to $80 \%$ of the total value, and it is important for both the buyer and the seller to protect the goodwill throughout the transaction[2]. Guijie Huang(2013) stressed that goodwill in the transaction price accounted for a lot, once accounted for more than $70 \%$ of the purchase price, and sometimes even up to $80 \%$ of the cost of the merger[3]. The goodwill we are talking about is the enterprise owned by the 
sum of intangible assets can be deducted from the individual after the remaining part of the intangible assets. Therefore, it derived the first method of valuation of goodwill, that is, cut the difference method. This method is from the definition of goodwill, and it is according to the difference between the value of the enterprise 's overall asset valuation and the sum of the appraisals of the individual assets that can be identified for goodwill assessment. Application of cut the difference method for goodwill assessment, will cause a greater error because of the error of individual assessment and evaluation methods and caliber different. In addition, From the essence of goodwill, cut the difference method failed to reflect the essence of goodwill is to bring excess returns from the essence of goodwill. Coupled with the artificially assessed factors, the difference between the value of the goodwill being evaluated and the value of the goodwill actually held by the enterprise can be significant. Therefore, the current goodwill assessment take the second method - excess return method. The excess return method is based on the essence of goodwill and calculate the enterprise more than its industry average earnings part, and the conversion to the current method. The key is the calculation of excess returns and discount rate to determine when apply it. The core part of the calculation of excess earnings is the estimation of the expected return. Enterprises for the assessment of goodwill is often carried out during the merger and reorganization. Therefore, we should take full account of the impact of mergers and acquisitions in the valuation of goodwill of merger and reorganization, especially for the expected benefits. In fact mergers and acquisitions will have a synergistic effect, simply say " $1+1>2$ ",so the revenue expectations are often not enough because of ignoring synergies. In the end, it creates an underestimation of the expected benefits, which affects the assessment of the value of goodwill. Xiuli Wang(2013)using the event study method to examine the market reaction of the A-share listed companies which generate goodwill after merger and acquisition in 2007-2010[4]. The empirical results show that merger and acquisition synergy is the source of excess returns. To sum up, the impact of merger and acquisition synergies can not be ignored when estimating excess returns.

\subsection{A Case Study of Goodwill Assessment}

According to the idea of excess return method to appraise the value of goodwill, a case of enterprise merger and acquisition is selected for the practical application of enterprise goodwill value evaluation. In this paper ,it selected the merger of China's two leading match-making websites Jiayuan and Baihe. Baihe announced combine Jiayuan in December 2015,and finish the merger in May,2016. In this paper, appraise the value of goodwill of this case.

1. Determine the base for the assessment of expected benefits. To predict the future benefits of Jiayuan, make sensitivity analysis of various factors influencing future returns. To the degree of change in the factors as the abscissa, the enterprise's yield as the vertical axis, by observing the influence of the slope to find the most influential factors. Through the analysis, found that operating income is the biggest factor that influence Jiayuan future revenue, so the net profit as the base to predict the future benefits.

2. Calculate the expected net profit growth rate. The Jiayuan went to the United States NASDAQ listed in 2011,so the published financial statements can be found in the relevant Web site according to the relevant disclosure system requirements. Extracted some of the useful data from the financial statements for the valuation of goodwill when the excess returns, and based on available data to calculate the current net profit growth rate. According to the moving average method to predict the future net profit growth, so predict the net profit growth rate of the future of the Jiayuan , details as following: 
Table 1 Key Indicator Analysis of Jiayuan

\begin{tabular}{|c|c|c|c|c|c|c|}
\hline & 2015 & 2014 & 2013 & 2012 & 2011 & 2010 \\
\hline $\begin{array}{l}\text { Total Revenue } \\
\text { (millions) }\end{array}$ & 714.00 & 614.00 & 493.00 & 411.00 & 331.00 & 168.00 \\
\hline Gross margin & $46.40 \%$ & $54.80 \%$ & $63.40 \%$ & $65.00 \%$ & $68.40 \%$ & $63.60 \%$ \\
\hline $\begin{array}{l}\text { Operating incom } \\
\text { (millions) }\end{array}$ & e 7.00 & 2.00 & 54.00 & 52.00 & 39.00 & 24.00 \\
\hline $\begin{array}{l}\text { Operating } \\
\text { profit margin }\end{array}$ & $0.9 \%$ & $0.4 \%$ & $11.00 \%$ & $12.60 \%$ & $12.00 \%$ & $14.30 \%$ \\
\hline $\begin{array}{l}\text { Net profit } \\
\text { (millions) }\end{array}$ & 25.00 & 20.00 & 64.00 & 59.00 & 37.00 & 17.00 \\
\hline \multicolumn{2}{|c|}{$\begin{array}{l}\text { Net profit growth } 25.00 \% \\
\text { rate for the period }\end{array}$} & - 68.75\% & $8.47 \%$ & $59.46 \%$ & $117.65 \%$ & I \\
\hline
\end{tabular}

A moving average of net profit growth rate is:

net profit growth rate $=(25.00 \%+<-68.75 \%>+8.47 \%+59.46 \%+117.65 \%) / 5=28.37 \%$

But taking into account the volatility of the Internet industry is relatively large, the net profit growth rate for a moving average is unscientific. So use the existing data for the second move averages to get net profit growth rate, seking to minimize uncertainties and the impact of unforeseen circumstances..

Table2 Forecast analysis of net profit growth rate of Jiayuan

\begin{tabular}{cccc}
\hline & Growth ratio of pevious period & Growth ratio of this period & Two-period average \\
\hline 2011 & $/$ & $117.65 \%$ & $/$ \\
2012 & $117.65 \%$ & $59.46 \%$ & $88.56 \%$ \\
2013 & $59.46 \%$ & $8.47 \%$ & $33.97 \%$ \\
2014 & $8.47 \%$ & $-68.75 \%$ & $-30.14 \%$ \\
2015 & $-68.75 \%$ & $25.00 \%$ & $-21.88 \%$ \\
\hline
\end{tabular}

Secondary moving average of net profit growth rate is:

net profit growth rate $=(88.56 \%+33.97 \%+<-30.14>+<-21.88>) / 4=17.63 \%$

3. To estimate the industry's net profit growth rate. In order to determine the excess returns, in addition to calculate the expected benefits of Jiayuan also estimate the industry's average profit.

Taking into account the data openness and authenticity, this paper selects several listed companies in the Internet social platform as the sample of average profit.The selected companies include Renren, Momo, Baihe, , and Tecent. Among them,Renren listed on the New York Stock Exchange,Baihe listed in the NEEQ,Momo listed in the United States NASDAQ, and Tecent listed in Hong Kong. The data with high accuracy for these companies can be found,and it help the industry average profit estimates. But after a preliminary analysis, the transformation of the road of Renren which start early is very difficult due to the rapid development of Internet social platform,so it result in a great deal of business problems in Renren.According to the data ,the net profit has fallen to-1428.59 millions last year. In view of this special situation, no longer considered for Renren when forecast industry average profits. In addition, due to Tencent's market share is large, close to 80\%,and Tencent's business covers a wide range, it is also far from the Jiayuan whether from the company size, company performance, corporate assets and so on. So it should be removed. And the rest of them, Momo and Baihe are close to Jiayuan whether from the main business, the size of the company, market share, or development track. So it is scientific to select the two companies to carry out calculations, and compare with Jiayuan. 
Table 3 The other companies in the industry net profit consolidation I

\begin{tabular}{lccccc}
\hline & 2015 & 2014 & 2013 & 2012 & 2011 \\
\hline Momo(millions) & 90.91 & -153.05 & -54.87 & -25.41 & $/$ \\
Renren(millions) & -1428.59 & 368.21 & 390.20 & -471.38 & $/$ \\
Baihe(millions) & -5.42 & -3.70 & -3.31 & $/$ & $/$ \\
Tecent(millions) & 29108.00 & 23888.00 & 15563.00 & 12784.85 & 10224.83 \\
\hline
\end{tabular}

Table 4 The other companies in the industry net profit consolidation II

\begin{tabular}{llccc}
\hline & 2015 & 2014 & 2013 & 2012 \\
\hline Momo(millions) & 90.91 & -153.05 & -54.87 & -25.41 \\
Net profit growth rate & $159.40 \%$ & $-178.93 \%$ & $-118.26 \%$ & $/$ \\
Baihe(millions) & -5.42 & -3.70 & -3.31 & $/$ \\
Net profit growth rate & $-46.49 \%$ & $-11.78 \%$ & $/$ & $/$ \\
\hline
\end{tabular}

The average of net profit growth rate of Momo is

net profit growth rate $=(159.40 \%+<-178.93 \%>+<-118.26>) / 3=-45.93 \%$

The average of net profit growth rate of Baihe is net profit growth rate $=(<-46.49 \%>+<-11.78>) / 2=-29.14 \%$

4. According to the estimated net profit growth rate to calculate excess returns.

Table 5 The expected net profit of Jiayuan

\begin{tabular}{lcccc}
\hline & 2016 & 2017 & 2018 & 2019 \\
\hline $\begin{array}{l}\text { Expected net profit } \\
\text { (millions) }\end{array}$ & 29.41 & 34.59 & 40.69 & 47.86 \\
\hline
\end{tabular}

Table 6 Analysis of the expected net profit of the other companies

\begin{tabular}{lcccc}
\hline & 2016 & 2017 & 2018 & 2019 \\
\hline Momo(millions) & 49.16 & 26.58 & 14.37 & 7.77 \\
$\begin{array}{l}\text { Baihe(millions) } \\
\begin{array}{l}\text { The average expected } \\
\text { Net profit (millions) }\end{array}\end{array}$ & -3.84 & -2.72 & -1.93 & -1.37 \\
\hline
\end{tabular}

Table 7 The analysis of excess earnings of Jiayuan

\begin{tabular}{lcccc}
\hline & 2016 & 2017 & 2018 & 2019 \\
\hline $\begin{array}{l}\text { Excess Revenue } \\
\text { (millions) }\end{array}$ & 6.75 & 22.66 & 34.47 & 44.66 \\
\hline
\end{tabular}

5. Determine discount rate. As the selected company is a listed company, financial data is easier to access. Therefore, in determining the discount rate, the choice of model to determine the discount rate is

$$
E\left(r_{i}\right)=R_{h}+\frac{D C L_{I}-D C L_{h}}{D C L_{h}} R_{h}
$$

To get the discount rate, we need to find the average return on assets and the associated leverage. From the selected number of listed companies to calculate the rate of average return on net assets is $23.54 \%$, and then calculate the financial leverage coefficient and operating leverage coefficient.

Enterprise comprehensive leverage coefficient $=1.06 * 2.37=2.51$

The industry's combined leverage coefficient $=1.24 * 1.51=1.87$

The discount rate $=23.54 \%+(2.51-1.87) * 23.54 \% / 1.87=31.14 \%$

6. From the above data, the value of Goodwill of Jiayuan is 48.91 millions Yuan.

Because of the synergistic effects of Baihe and Jiayuan, the future real income will be greater than expected, so the value of goodwill will be higher than the estimated value. 


\section{Conclusion}

In fact, the mergers and acquisitions transaction is bound to get synergistic effects. It is because there will be synergies, so mergers and acquisitions occurs. Synergistic effects refer to the overall effects that due to the common use of the same resources in production, marketing, management and so on. It can be understood as increasing competitiveness after the merger and acquisitions It can be understood as increasing competitiveness after the merger and acquisitions, or the combined results were higher than expected when the two companies were independent.. Therefore, the expected return will be greater than the assessment value, the result is the value of goodwill will be much higher than this assessment value in the end.

\section{References}

[1]. Weidong Feng, Haiying Zheng. Goodwill Accounting in Knowledge Economy: Theoretical Interpretation and Improvement . Research on Financial and Economic Issues. Vol.7 (2013) No. 11, p.92-96.

[2]. Frank Brown.The Value of Goodwill. Practice Transition Vol.9 (2015) No. 2, p.42-44.

[3]. Guijie Huang. On the Evaluation of Goodwill in M \& A. China Assets Appraisal. Vol.12 (2013) No.5, p.18-21.

[4]. Xiuli Wang. Goodwill in M \& A, Excess Earnings and Market Reactions - Evidence from China 's A Share Listed Companies. Xinjiang Finance and Economics. Vol.9 (2013) No.14, p.24-26.

[5]. Information on: https://xueqiu.com/

[6]. Information on: http://www.neeq.com.cn/ 